\title{
Dräktvariation hos hannar i skandinaviska populationer av svarthakad buskskvätta Saxicola rubicola
}

\section{Plumage variation of males in Scandinavian populations of European Stonechat Saxicola rubicola}

\author{
Reino Andersson \\ Rödaledstigen 6, 43253 Varberg, Sweden | samreinoandersson@gmail.com
}

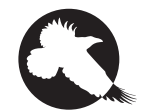

IN Western eUrope, the European Stonechat Saxicola rubicola, occurs in two subspecies; rubicola, with a large distribution in Europe, and hibernans, mainly distributed on the British Isles. A small population of presumed hibernans birds breed in Norway. However, difficulties in distinguishing hibernans from rubicola at an individual level has led to speculation regarding the origin of the Norwegian birds. There are no clear genetic differences between the subspecies and their plumage appearance can be considered to overlap within parts of the range. To investigate this, I studied the plumage variation among males during the breeding season in the Scandinavian populations of European Stonechats in Sweden, Norway and Denmark. The study is based on photos of 404 males during the period March-May. The presence or absence of six typical hibernans characteristics were registered for each individual. The results show that males with both hibernans and rubicola characteristics occur during the spring in the Scandinavian populations. There was a clear over-representation of males with hibernans characteristics in Norway as compared to Sweden, and to a lower degree also to Denmark. If the expansion of rubicola progresses in Scandinavia, one could expect a larger proportion of rubicola-like males in the Norwegian population.

Keywords: subspecies identification | Saxicola rubicola hibernans | photographic documentation | population expansion 


\section{Introduktion}

Svarthakad buskskvätta Saxicola rubicola förekommer med två underarter i Västeuropa: rubicola som återfinns inom stora delar av kontinenten och hibernans som har sin huvudsakliga utbredning på Brittiska öarna, framför allt på Irland och i Skottland. Smärre populationer av hibernans uppges finnas även i Portugal, Spanien, Frankrike och Norge (Cramp 1988, Urquhart 2002, Opaev 2018). I Skandinavien har den norska populationen varierat sedan första häckningen 1974 med som mest 50-100 par, medan de vissa perioder har varit försvunna, främst beroende på effekten av kalla vintrar (Størkersen 1994, Shimmings \& Øjen 2015). I Danmark konstaterades det första häckfyndet 1942, men först i början av 1990-talet skedde en markant ökning. Vid en uppskattning 2012 uppgick antalet revir till cirka 300. Från att ha varit bunden till hedbiotoper utmed Jyllands västkust, har den i takt med expansionen vidgat sitt biotopval och spridit sig även till inlandet (Dybbro 1976, Nyegaard m. fl. 2014). Den första häckningen i Sverige påträffades 2000 nära Simrishamn i Skåne. Fram till och med 2015 hade 25 häckningar konstaterats i landets södra och västra delar. Vid inventeringar som genomför- des häckningssäsongerna 2017 och 2018 registrerades 28 respektive 30 troliga eller säkerställda häckningar enbart på svenska västkusten (Andersson 2019).

Det har förekommit spekulationer kring de norska fåglarnas rastillhörighet och ursprung. Shirihai \& Svensson (2018) anger att de utgörs av rubicola, men uppgiften har senare reviderats till hibernans (M. Ullman in litt., L. Svensson in litt.). Urquhart (2002) anser att det rör sig om hibernans och att spridningen under 1970-talet till sydvästra Norges kustområden har skett från Orkney- och Shetlandsöarna. Den främsta orsaken till ovissheten kring den norska populationen har varit svårigheter att kunna särskilja raserna på individnivå. Man har i nuläget inte kunnat påvisa någon genetisk skillnad mellan hibernans och rubicola (Wink m. fl. 2002, Illera m.fl. 2008, Zink m.fl. 2009, van Doren m.fl. 2017). Båda underarterna anses dessutom överlappa varandra i dräktutseende inom vissa delar av utbredningsområdet, med en kontinuerlig övergång mot allt mörkare fåglar i väst och nordväst. Genomsnittliga morfologiska skillnader har dock kunnat påvisas när längre serier av fåglar har granskats (Urquhart 2002, Clements 2015, Opaev

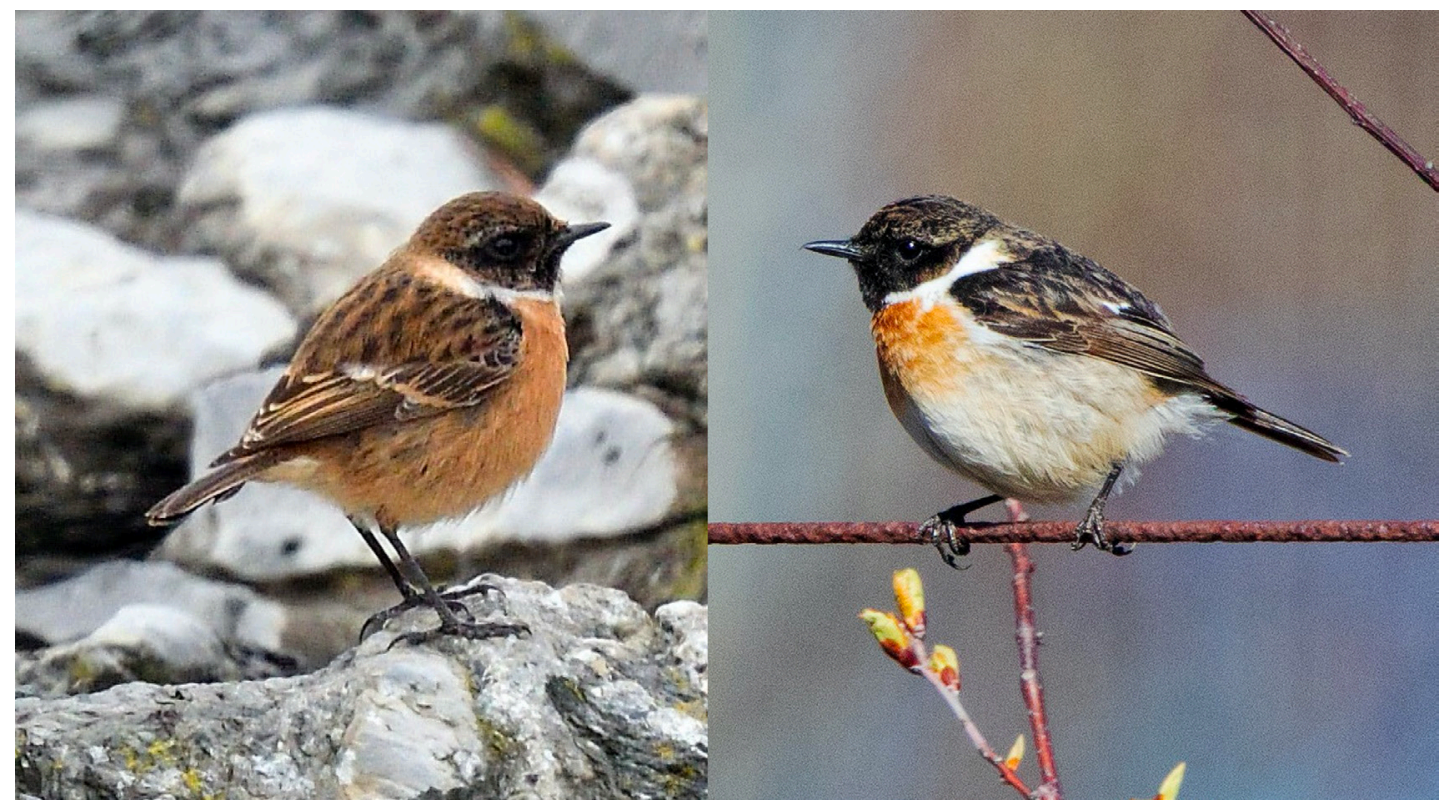

FIGUR 1. Hannar av svarthakad busksvätta Saxicola rubicola med typiska hibernans-karaktärer (vänster; Fornebu, Akershus, 16 mars 2019 . Foto: Andreas Gullberg) respektive rubicola-karaktärer (höger; Södra Järvafältet, Uppland, 5 april 2017. Foto: Olle Bernard).

- Males of European Stonechat Saxicola rubicola with typical hibernans characteristics (left; Fornebu, Akershus, 16 March 2019. Photo: Andreas Gullberg) and rubicola characteristics, (right; Södra Järvafältet, Uppland, 5 April 2017. Photo: Olle Bernard), respectively. 
2018). Hannar av svarthakad buskskvätta i Norge har en påfallande likhet med skotska hibernans som generellt är mörkare än rubicola. Ett fynd som möjligen styrker att den norska populationen härrör från Brittiska öarna gjordes 26 mars 2016, då en färgringmärkt hona blev fotograferad och avläst vid Søgne, Vest-Agder, i södra Norge. Denna fågel visade sig vara märkt som bounge i Norfolk i sydöstra England 7 juni 2015 (Secker 2016).

Norska faglar är i likhet med brittiska i stor utsträckning stannfåglar, till skillnad från svarthakade buskskvättor i Sverige och Danmark, där praktiskt taget alla flyttar. Stannfåglar producerar generellt fler kullar under en säsong än flyttande populationer (Cramp 1988, Størkersen 1994, Urquhart 2002). I Norge har upp till fyra kullar konstaterats, medan som mest två kullar registrerats på svenska västkusten (Bringsvor 2015, Andersson 2019). En del av de norska fagglarna flyttar dock bevisligen, vilket framgår av två intressanta återfynd. En hanne märkt på Lista, Vest-Agder, på sydkusten i augusti 2000 blev avläst utanför Halmstad i februari 2002. Senare samma vår var hannen tillbaka som häckfågel på Lista. En annan hanne märkt som bounge på Sandsøya, Møre og Romsdal, i västra Norge 17 maj 2018, återfanns mellan november 2018 och februari 2019 vid Elbes utlopp i norra Tyskland, 95 mil sydost om födelseplatsen (Bringsvor 2019). Vid en sökning i svenska Artportalen (www.artportalen.se) återfinns ett tiotal individer som fotograferats i Sverige under vintern. Dessa överensstämmer väl med hibernans karaktärer. Liksom faggeln i Halmstad rör det sig sannolikt om norska fåglar som övervintrat i Sverige.

Hannar med typiska hibernans-karaktärer har under våren bland annat relativt breda, mörkt rödbruna bräm på hjäss-, mantel- och ryggfjädrar. Bröst och flanker är mörkt rödbruna. Den vita halskragen är förhållandevis smal med rödbruna inslag. Hos hannar med rubicola-karaktärer ersätts de mörkt rödbruna brämen av en ljust beige/gråbrun nyans. Buk och flanker uppvisar vanligtvis en begränsad beige-orange färgton mot vitaktig botten. Mörkhetsgraden är mer påtaglig hos båda raserna i fräsch höstdräkt än på våren, då fåglarna hunnit slita sin fjäderdräkt (Urquhart 2002, Shirihai \& Svensson 2018).

Oklarheterna kring de norska häckfåglarnas ursprung föranledde mig att undersöka dräktvariationen hos hannar under häckningstid i de skandinaviska populationerna i Sverige, Norge och Danmark. Förut- om att spegla spridningen av olika dräktutseenden kan detta ge indikationer på hibernans respektive rubicolas status i dessa områden.

\section{Material och metoder}

Materialet baseras på fotografier av 404 olika hannar, relativt jämnt utspridda över häckningsperioden marsmaj (tabell 1). Vid denna period på våren förefaller hannarna vara lättare att klassificera, då skillnaderna framträder tydligare till följd av slitage. Skälet till den tidsmässiga begränsningen är att undvika alltför stor spridning i slitaget hos de olika individerna. Det förekommer hannar med hibernans-karaktärer såväl i mars som i maj och samma förhållande råder när det gäller individer med rubicola-karaktärer. De fördelas på 240 svenska, 89 danska och 75 norska fåglar, huvudsakligen under den senaste tioårsperioden. Bilderna till granskningen är hämtade från svenska www.artportalen.se, norska www.artsobservasjoner.no, danska www.dofbasen.dk och www.netfugl.dk. och sträcker sig till och med mars 2019. För elva hannar i det svenska materialet, där foton publicerats senare än maj, har privata bilder efterfrågats och utnyttjats. Honor valdes bort, då deras dräktutseende är svårare att bedöma och klassificera.

Studien utgår från samtliga foton som varit tillräckligt bra för att kunna göra en bedömning. I de flesta fall har det medfört ett flertal foton ur olika vinklar på samma individ. En svaghet med metoden är dock att urvalet inte är slumpmässigt, utan beroende av den spontana bildrapporteringen till de olika databaserna. Om det inneburit någon snedfördelning eller premiering av

TABELL 1. Månads- och landsvis fördelning av de studerade hannarna av svarthakad buskskvätta Saxicola rubicola. Siffrorna inom parentes anger antalet hannar som uppvisat samtliga sex hibernans-karaktärer.

- Monthly distribution of the number of studied European Stonechat Saxicola rubicola males per country. Number of males with all six hibernans characteristics are shown within parentheses.

\begin{tabular}{lcccccc}
\hline $\begin{array}{l}\text { Månad/Land } \\
\text { Month/Country }\end{array}$ & $\begin{array}{l}\text { Sverige } \\
\text { Sweden }\end{array}$ & $\begin{array}{l}\text { Norge } \\
\text { Norway }\end{array}$ & $\begin{array}{l}\text { Danmark } \\
\text { Denmark }\end{array}$ \\
\hline Mars March & 68 & $(5)$ & 42 & $(35)$ & 30 & $(11)$ \\
April April & 87 & $(4)$ & 22 & $(9)$ & 26 & $(6)$ \\
Maj May & 85 & $(1)$ & 11 & $(8)$ & 33 & (3) \\
\hline
\end{tabular}


vissa hannar är svårt att bedöma. Värdet med studien torde ändå vara att, utifrån befintligt bildmaterial, ge en preliminär översikt som skulle kunna utgöra en grund för framtida undersökningar.

Jag har valt att utgå från sex typiska hibernanskaraktärer som tidigare har beskrivits av olika aukto-

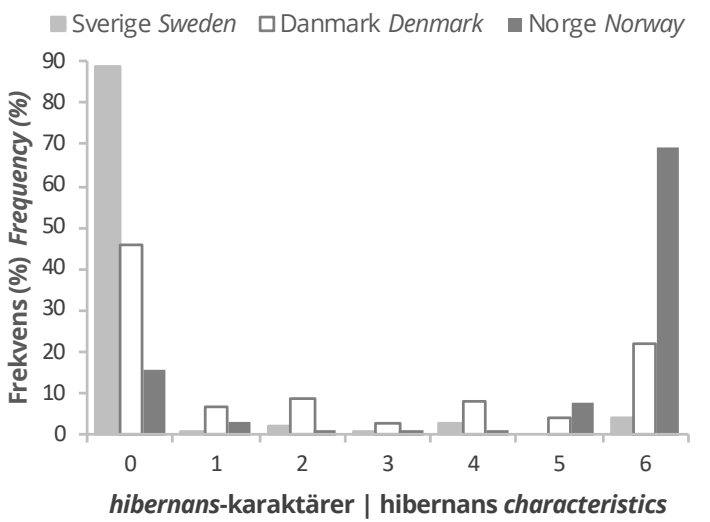

FIGUR 2. Fördelning över 0-6 hibernans-karaktärer hos hannar av svarthakad buskskvätta Saxicola rubicola i Sverige, Danmark och Norge. 0 anger att en individ saknar karaktärerna helt, 1-5 att en till fem av karaktärerna noterats, 6 att samtliga sex karaktärer registrerats hos samma individ.

- Distribution over 0-6 hibernans characteristics in male European Stonechats Saxicola rubicola in Sweden, Denmark and Norway. 0 means that an individual completely lacks the characteristics, 1-5 that one to five of the characteristics have been noted and 6 means that all six criteria are fulfilled.

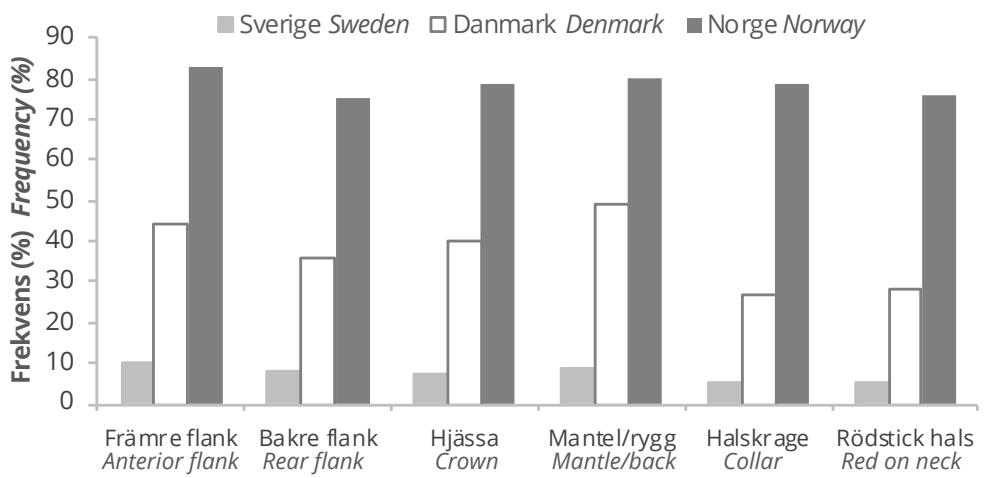

hibernans-karaktärer | hibernans characteristics

FIGUR 3. Procentuell närvaro av sex studerade hibernans-karaktärer hos svenska, danska och norska hannar av svarthakad buskskvätta Saxicola rubicola.

- Percentage of the studied hibernans characteristics present in the Swedish, Danish and Norwegian

European Stonechats Saxicola rubicola males. riteter och som gått att registrera utifrån bildmaterialet (jfr figur 1, Cramp 1988, Urquhart 2002, Shirihai \& Svensson 2018). De studerade hibernans-karaktärerna är följande:

1) Främre flanken (fjäderfältet nedanför större täckarraden) är mörkt rödbrun.

2) Bakre flanken (fjäderfältet ovanför benet närmast vingen) är mörkt rödbrun.

3) Hjässan har relativt breda mörkt rödbruna bräm.

4) Mantel/rygg har relativt breda mörkt rödbruna bräm.

5) Halskragen är förhållandevis smal.

6) Halskragen har rödbruna inslag i det vita.

Närvarograden av dessa sex karaktärer har registrerats hos varje fotograferad individ. Kriterierna har genomgått en likartad och jämförbar klassificering utförd av författaren.

\section{Resultat}

Betraktar man utfallet av hibernans-karaktärer hos enskilda individer framträder ett tydligt mönster (figur 2). I Sverige saknar $89 \%$ av de undersökta hannarna karaktärerna helt, $7 \%$ uppvisar en till fem av karaktärerna, medan bara $4 \%$ uppvisar alla sex karaktärerna. Fåglarna i Norge uppvisar ett motsatt förhållande där $69 \%$ av hannarna bär samtliga hibernans-karaktärer, $15 \%$ en till fem av karaktärerna och $16 \%$ saknar karaktärerna fullständigt. Den erhållna bilden för Danmark hamnar någonstans däremellan, med $46 \%$ av hannarna som helt saknar karaktärerna, $32 \%$ som saknar en till fem av karaktärerna och $22 \%$ med närvaro av samtliga. Figur 3 visar att närvaron av de sex hibernans-karaktärerna är relativt jämnt fördelade inbördes i de tre länderna.

Det går inte att fastslå något geografiskt mönster av hibernans-fynd med alla 
sex karaktärerna i Sverige eller Danmark, då de är utspridda inom respektive utbredningsområde. Hannar i Norge med rubicola-karaktärer (dvs. avsaknad av de sex hibernans-karaktärerna), är däremot endast påträffade i södra och sydöstra delarna av landet. Detta trots att artens utbredning och bildunderlaget under den aktuella tidsperioden mars-maj även har omfattat västra Norges kustområden (figur 4).

\section{Diskussion}

Diskussioner om taxonomi och rasförhållanden hos svarthakad buskskvätta har pågått länge (t. ex. Hellström m. fl. 2011, Hellström m. fl. 2014). Flera av underarterna är förhållandevis välstuderade i delar av sitt utbredningsområde, medan situationen hos andra, däribland hibernans, är mer oklar (t. ex. Illera 2008).

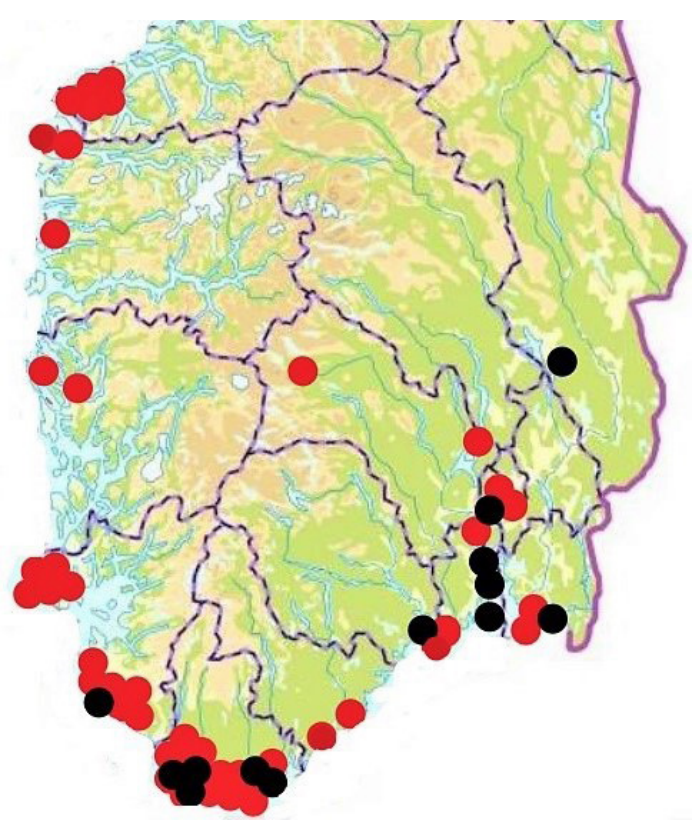

FIGUR 4. Studerade hannar av svarthakad buskskvätta Saxicola rubicola fotograferade i södra Norge, som uppvisar samtliga sex hibernans-karaktärer (röda punkter) samt hannar med rubicola-karaktärer som saknar hibernans-karaktärer helt (svarta punkter). Kartunderlag: www.artsobservasjoner.no, www.kartverket.no.

- Studied European Stonechats Saxicola rubicola males photographed in southern Norway, showing all six hibernans characteristics (red dots) and males with rubicola characteristics that lack the hibernans characteristics entirely (black dots). Maps from www. artsobservasjoner. no and www.kartverket.no.
Dess existens har ifrågasatts i vissa angivna områden, exempelvis Portugal (t. ex. Siddle 2006). Somliga har menat att det istället för underarter i Västeuropa snarast handlar om en övergång av olika morfer med allt mörkare fagglar i väst och nordväst. Andra hävdar att det trots avsaknad av genetiska skillnader och morfologisk överlappning, rör sig om två fullvärdiga underarter (t. ex. Urquhart 2002, Illera m. fl. 2008).

Denna studie visar att hannar med både hibernansoch rubicola-karaktärer förekommer under våren i de skandinaviska populationerna. Skillnaderna i dräktutseende är tydliga, med en överrepresentation av hannar med hibernans-karaktärer i Norge jämfört med Sverige. Detsamma gäller jämförelser mellan Norge och Danmark men inte i lika hög grad. Möjligen skulle Danmarks relativt stora inslag av sådana hannar kunna bero på det geografiska läget närmare Norge och Storbritannien. I Sverige däremot är hannar med hibernanskaraktärer under häckningstid mycket fåtaliga. Förekomsten av rubicola-lika hannar i södra och sydöstra Norge skulle möjligen kunna indikera en pågående spridning från den danska eller svenska populationen. I takt med en fortsatt expansion av rubicola skulle man framgent kunna förvänta sig ett större inslag av rubicolalika hannar i den norska populationen. Ytterligare efterforskningar, t. ex. fler riktade och kontrollerade märkinsatser, krävs dock för att erhålla en tillförlitligare bild av hibernans och rubicolas status i Skandinavien.

\section{Tack}

Tack till Andreas Gullberg och den framlidne Olle Bernard för fotona som illustrerar denna uppsats. Tack till Robin Andersson, Magnus Hellström, Andreas Gullberg och Per Undeland för granskning av manuskriptet. Tack också till Lars Svensson, Leif Jonasson och Anders Nothagen för värdefulla synpunkter.

\section{Referenser}

Andersson R. 2019. Populationsutveckling hos svarthakad buskskvätta Saxicola rubicola under expansionens inledningsskede i Västsverige. Ornis Svecica 29: 26-36. https://doi.org/10.34080/ os.v29.19555

Bringsvor IS. 2015. Ett år i svartstrupas rike. http://ingarsfuglebilder. blogspot.com/2015/o3/eit-ar-i-svartstrupas-rike.html

Bringsvor IS. 2019. Første funn utanfor Skandinavia. http://ingarsfuglebilder.blogspot.com/2019/o4/frste-funn-utanfor-skandinavia. html 
Clements P \& Rose C. 2015. Robins and Chats. Helm, London.

Cramp S. 1988. The Birds of the Western Palearctic. Oxford University Press, Oxford.

van Doren B, Campagna L, Helm B, Illera JC, Lovette IJ \& Liedvogel M. 2017. Correlated patterns of genetic diversity and differentiation across an avian family. Molecular Ecology 26: 3982-3997. https:// doi.org/10.1111/mec.14083

Dybbro T. 1976. De danske ynglefugles udbredelse. Dansk Ornitologisk Forening, København.

Hellström M \& Norevik G. 2014. The uppertail-covert pattern of 'Stejneger's Stonechat'. British Birds 107: 692-700.

Hellström M \& Waern M. 2011. Field identification and ageing of Siberian Stonechats in spring and summer. British Birds 104: 236-254.

Illera JC, Richardson DS, Helm B, Atienza JC \& Emerson BC. 2008. Phylogenetic relationship, biogeography and speciation in the avian genus Saxicola. Molecular Phylogenetics and Evolution 48: 1145-1154. https://doi.org/10.1016/j.ympev.2008.05.016

Nyegaard T, Meltofte H, Tofft J \& Grell MB. 2014. Truede og sjældne ynglefugle i Danmark 1998-2012. Dansk Ornitologisk Forenings Tidskrift 108: 1-144. Available at https://www.dof.dk/images/ projekter/truedeynglefugle/dokumenter/DOFT_1_2014.pdf

Opaev A, Redkin Y, Kalinin E \& Golovina M. 2018. Species limits in Northern Eurasian taxa of the common stonechats, Saxicola torquatus complex (Aves: Passeriformes, Muscicapidae). Vertebrate Zoology 68: 199-211.
Secker J. 2016. First British-ringed Stonechat for Norway - rubicolus? http://btoringing.blogspot.com/2016/o4/first-british-ringedstonechat-for.html

Shimmings P \& Øjen IJ. 2015. Bestandsestimater for norske hekkefugler. NOF-rapport 2-2015. Norsk Ornitologisk Forening, Trondheim. Available at http://www.birdlife.no/innhold/ bilder/2016/o3/17/3739/nof_rapport_bestandsestimater.pdf

Shirihai H \& Svensson L. 2018. Handbook of Western Palearctic Birds. Helm, London.

Siddle J. 2006. Which subspecies of Common Stonechat breeds in coastal Portugal? British Birds 99: 372-375.

Størkersen ØR. 1994. Svartstrupe Saxicola torquata. Pp 36o-361 in Norsk Fugleatlas (Gjershaug JO, Thingstad PG, Eldøj S \& Byrkjeland S, eds). Norsk Ornitologisk Forening, Klæbu. Available at http://www.birdlife.no/fuglekunnskap/fugleatlas/index. php?taxon_id=9799

Urquhart E. 2002. Stonechats: a Guide to the Genus Saxicola. Helm, London.

Wink M, Sauer-Gurth H \& Gwinner E. 20o2. Evolutionary relationships of stonechats and related species inferred from mitochondrial-DNA sequences and genomic fingerprinting. British Birds 95: 349-355.

Zink RM, Pavlova A, Drovetski S, Wink M \& Rohwer S. 2009. Taxonomic status and evolutionary history of the Saxicola torquata complex. Molecular Phylogenetics and Evolution 52:769-773. https:// doi.org/10.1016/j.ympev.2009.05.016

\section{English Summary}

European Stonechat Saxicola rubicola occurs with two subspecies in Western Europe: rubicola found in large parts of the continental Europe, and hibernans mainly confined to the British Isles, especially Ireland and Scotland. Minor populations of hibernans have been reported also in Portugal, Spain, France and Norway (Cramp 1988, Urquhart 2002, Opaev 2018).

The origin and taxonomic status of Norwegian birds have been a matter of speculation for some time. According to Shirihai \& Svensson (2018), they consist of rubicola, but that information has later been revised to hibernans (M. Ullman, L. Svensson, in litt.). Urquhart (2002), on the other hand, believes that they are hibernans that have dispersed from the Orkney and Shetland Islands to the southwestern coastal areas of Norway during the 1970s. The main reason to the uncertainties regarding the Norwegian population is the difficulties in distinguishing the subspecies on an individual level.

So far, molecular studies have not shown any genetic differences between hibernans and rubicola (Wink et al. 2002, Illera et al. 2008, Zink et al. 2009, van Doren et al. 2017). In addition, the plumage appearance of the two subspecies are considered to overlap within certain parts of the range, with a continuous transition towards darker birds in west and northwest. However, when larger number of birds have been examined, it has been possible to see morphological differences in an average sense (Urquhart 2002, Clements 2015, Opaev 2018). Norwegian males have a remarkable similarity to Scottish hibernans, which are in general darker than rubicola. One finding that possibly supports the claim that the Norwegian population originates from the British Isles was made on the 26th of March 2016, when a colour-ringed female was photographed and observed close to Søgne, Vest-Agder in southern Norway. This individual turned out to be ringed as nestling in Norfolk in southwestern England on the 7 June 2015 (Secker 2016).

During spring, males with typical hibernans characteristics appear with relatively wide, dark red-brown tips and fringes on crown and upperparts. Breast and flanks are dark red-brown. The white neck patch is relatively narrow with red-brown fillings. The dark redbrown fringes are replaced by a light buff/grey-brown 
tone for males with rubicola characteristics. Usually, the underparts and flanks appear as a limited buff-orange colour tone on a white bottom. Both subspecies are darker and more contrasting in fresh autumn plumage, compared to spring when the birds have a more worn plumage (Urquhart 2002, Shirihai \& Svensson 2018).

The ambiguities regarding the origin of the Norwegian breeding birds prompted me to investigate the plumage variation in males during breeding season in the Swedish, Norwegian and Danish populations. In addition to reflect the geographical spread of the plumage variation, the purpose was to provide the current status of hibernans and rubicola in these particular areas.

The material is based on photos of 404 different males, relatively evenly distributed over the breeding season March-May (see Table 1). During this time of the spring, the males seem to be more easily classified since wear makes the differences appear clearer. By limiting the time scope to this period, it was possible to avoid a too large variation of the wear between the different individuals. In the material there were males with hibernans characteristics in both March and May and the same holds true for individuals with rubicola characteristics. The material consisted of 240 Swedish, 89 Danish and 75 Norwegian birds that have mainly been observed within the last ten years. The photos were obtained from four different websites; Swedish www.artportalen.se, Norwegian www.artsobservasjoner.no as well as the Danish www.dofbasen.dk and www.netfugl.dk. Females were disregarded since the difference in plumage is subtler and thereby difficult to classify.

The study included all photos up to March 2019 that were of sufficiently good quality to make a judgment. In most cases, several photos were available, showing the individual from different angles. One drawback with this method, however, is that the samples are not random, but dependent on spontaneous reports submitted to the different databases. If this has biased the results is difficult to judge. In any case, the purpose of the study is to give a preliminary overview, based on the existing photo material, and possibly provide a foundation for future studies.

I chose to base the classification on six typical hibernans characteristics that are possible to apply to the photo material. These characteristics have been described in the literature by other authors (cf. Figure 1 ,
Cramp 1988, Urquhart 2002, Shirihai \& Svensson 2018). The considered hibernans characteristics are the following:

1) Anterior flank (feathers below the grater coverts) is dark red-brown.

2) Rear flank (feathers above the leg near the wing) is dark red-brown.

3) Crown has relatively wide dark red-brown tips and fringes.

4) Upperpart have relatively wide dark red-brown tips and fringes.

5) Neck patch is relatively narrow.

6) Neck patch has red-brown fillings in the white.

The presence of these six characteristics were registered for each individual. All classifications were carried out by the author in a manner as consistent and comparable as possible.

The proportion of recorded hibernans characteristics varied substantially between the investigated populations. In Sweden, $89 \%$ of the males completely lacked hibernans characteristics, $7 \%$ had one to five, and $4 \%$ displayed all six characteristics. In Norway the distribution was opposite, with $69 \%$ of the males displaying all hibernans characteristics, $15 \%$ one to five and $16 \%$ lacking the characteristics. Interesting, in Denmark the distribution was somewhere in between Sweden and Norway, with $46 \%$ of the males completely lacking the characteristics, $32 \%$ showing one to five and $22 \%$ showing all six (Figure 2). Figure 3 shows that the presence of the six different hibernans characteristics occurred in equal ratio in the three countries.

Since there is a certain spread within each respective range in Sweden and Denmark, it is not possible to conclude any geographical pattern of the hibernans findings that fulfil all six criteria. The material studied indicate that males showing rubicola characteristics (i.e. absence of the six hibernans characteristics) in Norway are mainly found in the southern and southeastern parts of the country (Figure 4).

The taxonomy of the European Stonechat has been discussed for a long time (e.g. Hellström et al. 2011, Hellström et al. 2014). Several of the subspecies are relatively well examined in parts of their range, while the situation among others, e.g. hibernans, is more unclear (e.g. Illera 2008). Its existence in certain areas, e.g. Portugal, 
has been questioned (e.g. Siddle 2006). Some claim that it is a transition of different morphologies with darker birds in west and northwest rather than subspecies in Western Europe. Despite morphological overlap and a lack of genetic differences, others claim that there are in fact two different subspecies (e.g. Urquhart 2002, Illera etal. 2008).

This study shows that both hibernans- and rubicolalike males are present in the Scandinavian populations during the breeding time in spring. The differences in plumage are clear, with an over-representation of males with hibernans characteristics in Norway as compared to Sweden. The same, although not to the same degree, can be said regarding comparisons between Norway and Denmark. The relatively large proportions of such males in the Danish population could possibly be explained by the geographical location closer to Norway and Great Britain. Males with hibernans characteristics are very rare in Sweden during the breeding season. The presence of rubicola-like males in southern and southeastern Norway could be due to the Danish and Swedish populations spreading north. As the expansion of rubicola progresses, one could expect a larger proportion of rubicola-like males in the Norwegian population. More research, e.g. targeted and controlled ringing activities, is however necessary to obtain a more accurate picture of the current status of hibernans and rubicola in Scandinavia.

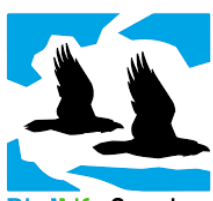

Ornis Svecica (ISSN 2003-2633) is an open access, peer-reviewed scientific journal published in English and Swedish by BirdLife Sweden. It covers all aspects of ornithology, and welcomes contributions from scientists as well as non-professional ornithologists. Accepted articles are published at no charge to the authors. Read papers or make a submission at os.birdlife.se.

Ornis Svecica (ISSN 2003-2633) är en fritt tillgänglig granskad vetenskaplig tidskrift som ges ut på svenska och engelska av BirdLife Sverige. Den täcker ornitologins alla områden och välkomnar bidrag från såväl forskare som icke-professionella ornitologer. Accepterade uppsatser publiceras utan kostnad för författarna. Läs uppsatser eller skicka in ditt bidrag på 